\title{
Developing a New Stock Index for Vietnam's Securities Market
}

\author{
NGUYẼ̃N HŨ̃U HUÂN
}

University of Economics, HCMC - huannguyen@ueh.edu.vn

\begin{tabular}{|c|c|}
\hline ARTICLE INFO & ABSTRACT \\
\hline $\begin{array}{l}\text { Article history: } \\
\text { Received: } \\
\quad \text { June 25, } 2013 \\
\text { Received in revised form } \\
\quad \text { Sep 10, } 2013 \\
\text { Accepted: } \\
\quad \text { March 31, } 2014 \\
\begin{array}{l}\text { Keywords: } \\
\text { Stock market, stock index, } \\
\text { stock exchange. }\end{array}\end{array}$ & $\begin{array}{l}\text { Stock market index plays an important role as a measure of } \\
\text { development of securities markets of a country or a region. Results of } \\
\text { this empirical research show that in its } 13 \text { years of development, } \\
\text { Vietnamese securities market indexes only had limited values because } \\
\text { of their poor market representation and predictive power, implying the } \\
\text { need to merge Hà Nội and HCMC stock exchanges. The research } \\
\text { suggests a new set of stock market indexes to deal with shortcomings } \\
\text { of existing indexes, thereby providing relevant entities with a new } \\
\text { view on development of securities market in Vietnam. }\end{array}$ \\
\hline
\end{tabular}




\section{INTRODUCTION}

Stock market plays an important role in raising investment and is an attractive investment channel to both institutional and individual investors. General market indexes can provide an overview of stock market, its development and its effects on the economic growth.

As an infant stock market, Vietnam's stock exchanges, at present, still lack stock indices that can fulfill their functions and serve as a solid basis for investors in their decision making process. In the market, VN-Index and HNX-Index have exposed many shortcomings such as low market representativity, poor predictive power and being affected easily by stock codes with high market capitalization. Thus, this paper aims to evaluate present indices of stock market and suggest some measures to build new stock indices in order to provide investors with more viable look at stock market in particular and securities market in general in Vietnam.

\section{APPROPRIATE INDEX}

\section{a. Theoretical Bases:}

A security market index represents a particular security market, market segment, or asset class. Most indices are constructed as portfolios of marketable securities (Sandte, 2012).

McMillan et al. (2011) point out that "indices were initially created to give a sense of how a particular security market performed on a given day. With the development of modern financial theory, their uses in investment management have expanded significantly. Some of the major uses of indices include:

- Gauges of market sentiment.

- Proxies for measuring and modeling returns, systematic risk, and risk-adjusted performance.

- Proxies for asset classes in asset allocation models.

- Benchmarks for actively managed portfolios.

-Model portfolios for such investment products as index funds and exchange-traded funds (ETFs).

- Economic forecasts 
Investors using security market indices must be familiar with how various indices are constructed in order to select the index or indices most appropriate for their needs."

\section{b. Literature Review}

There are many researches testing predictive power of stock index for economic growth in a country, and they have become the popular topic of empirical researches (Levine, 1997).

The correlation between the economic growth and financial market indices was first studied by Goldsmith (1969), McKinnon (1973), and Shaw (1973) who found some evidences of this relationship. Moreover, various theories are also developed from these empirical researches by, for example, Greenwood \& Jovanovic (1990) and Pagano (1993), who find evidences of the positive impact of financial indices on the economic growth.

Ake \& Dehuan (2010) use Granger Causality Test to detect the relationship between securities market and economic growth through market capitalization, total trading value, and market return in several countries. The research results indicate a positive relationship between securities market and economic growth in France and the United Kingdom, but this relationship is not found in Portugal and Belgium.

Harris (1997) conducts an empirical research on relationship between securities markets and economic growth and concludes that there is no clear evidence of support from activities in this market for economic development.

In the study by Ake \& Ognaligui (2010), the relationship between securities market and economic growth in Cameroon is again examined using Granger Causality Test based on the time series data from 2006 to 2010. The research findings indicate that Douala Stock Exchange Index does not affect Cameroonian economic growth.

Regarding the level of market representativity of stock index, many organizations in the world have also tested indices that they launched, such as FTSE, S\&P500, Dow Jones, etc.

\section{DATA AND METHODOLOGY}

\section{a. Methodology:}

Through previously conducted empirical researches, the author uses quantitative analysis to test the effectiveness of stock indices in Vietnam's stock market based on two criteria: 
- Predictive power: VAR model is used to evaluate predictive power of indices under consideration.

The suggested VAR model includes two endogenous variables $\mathrm{y}_{1 \mathrm{t}}$ and $\mathrm{y}_{2 \mathrm{t}}$

$$
\mathrm{y}_{1 \mathrm{t}}=\beta_{10}+\beta_{11} \mathrm{y}_{1 \mathrm{t}-1}+\cdots+\beta_{1} \mathrm{k} \mathrm{y}_{1 \mathrm{t}-\mathrm{k}}+\alpha_{11} \mathrm{y}_{2 \mathrm{t}-1}+\cdots+\alpha_{1 \mathrm{k}} \mathrm{y}_{2 \mathrm{t}-\mathrm{k}}+\mathrm{u}_{1 \mathrm{t}}
$$

$\mathrm{y}_{2 t}=\beta_{20}+\beta_{21} \mathrm{y}_{2 \mathrm{t}-1}+\cdots+\beta_{2} \mathrm{y}_{2 \mathrm{t} t \mathrm{k}}+\alpha_{21} \mathrm{y}_{1 \mathrm{t}-1}+\cdots+\alpha_{2} \mathrm{k} \mathrm{y}_{1 \mathrm{t}-\mathrm{k}}+\mathrm{u}_{2 \mathrm{t}}$

Where:

$\mathrm{y}_{1 \mathrm{t}}$ : Second difference of GDP (D (GDP, 2)

$\mathrm{y}_{2 \mathrm{t}}$ : Second difference of VN-Index, VN30 (D, VN30, 2)

$\mathrm{u}_{1 \mathrm{t}}$ : Error (residual) of GDP

$\mathrm{u}_{2 \mathrm{t}}$ : Error (residual) of VN-Index, VN30

$\mathrm{y}_{1 t-\mathrm{k}}$ : Lag variable of $\mathrm{y}_{1 \mathrm{t}}$ with $\mathrm{k}$ as lag order.

- Market representativity of stock indices: the author uses regression coefficient and charts of time to evaluate the representativity of stock indices.

Effectiveness of VN-Index and VN30 offered by the HCMC Stock Exchange (HOSE) are tested in this research because their market representativity is higher than HNX-Index or HNX30-Index announced by the Hà Nội Stock Exchange. HOSE stock indices represent stock codes with high capitalization value and the HOSE total capitalization value is NINE times higher than the HNX one (VND643,000 billion of HOSE compared to VND83,000 billion of HNX).

\section{b. Data:}

Data were gathered from Q2/2005 to Q4/2012 for VN-Index and GDP and from $\mathrm{Q} 1 / 2009$ to $\mathrm{Q} 4 / 2012$ for $\mathrm{VN} 30$ in order to test their predictive power.

To evaluate the market representativity of VN-Index and VN30, the author removes four stock codes with the highest capitalization value of VN-Index (MSN, BVH, VNM, and VIC) from the codes basket and rebuilds a new index called VN-Index2, then testing the correlation between VN30 and VN-Index2. Data of 989 observations were gathered from Jan. 2, 2009 to Dec. 31, 2012 [1].

\section{RESUTLS AND DISCUSSIONS}

\section{a. Testing the Correlation between VN-Index, VN-30 and GDP:}

To ensure that the time series data of GDP and VN-Index, VN30 are appropriate, the author tests stationarity of those two indices before testing the relationship between GDP 
and VN-Index, VN30. The following Table 1 indicates that data series are stationary at their second difference.

Table 1: Results of Stationarity Test

\begin{tabular}{ccc}
\hline Variable & ADF Test & Status \\
\hline VN-Index & $0.0089^{* * *}$ & Stationary \\
GDP & $0.0001^{* * *}$ & Stationary \\
VN30 & $0.0385^{* *}$ & Stationary \\
\hline
\end{tabular}

Source: Author's calculations

\section{b. Appropriate Lag Order for VAR Model:}

The VAR model is tested by selection of appropriate lag orders of endogenous variables.

Table 2: Appropriate Lag Orders for VAR Model of VN-Index and GDP

\begin{tabular}{ccccccc}
\hline Lag & LogL & LR & FPE & AIC & SC & HQ \\
\hline 2 & -302.1288 & 7.395649 & $6.87 \mathrm{e}+08$ & 26.01073 & 26.50159 & 26.14096 \\
3 & -267.7059 & $48.76570^{*}$ & $55651659 *$ & $23.47550^{*}$ & $24.16269 *$ & $23.65781^{*}$ \\
4 & -266.8033 & 1.128315 & 75132851 & 23.73361 & 24.61715 & 23.96801 \\
\hline
\end{tabular}

Source: Author's calculations

Table 3: Appropriate Lag Orders for VAR Model of VN-30 and GDP

\begin{tabular}{ccccccc}
\hline Lag & LogL & LR & FPE & AIC & SC & HQ \\
\hline 2 & -126.1504 & 5.128668 & $2.23 \mathrm{e}+08$ & 24.75463 & 25.11635 & 24.52661 \\
3 & -107.2950 & $13.71305^{*}$ & $20595490^{*}$ & $22.05364^{*}$ & $22.56005^{*}$ & $21.73441^{*}$ \\
\hline
\end{tabular}

Source: Author's calculations

Tables 2 and 3 show that both VAR models have 3 as their appropriate lag value, according to LR, FPE, AIC, CS and HQ, where:

LR: sequential modified LR test statistic

FPE: Final prediction error

AIC: Akaike information criterion 
SC: Schwarz information criterion

HQ: Hannan-Quinn information criterion

\section{c. Causality Test:}

Wald test (VAR Granger Causality/Block Exogeneity Wald) is used for testing the causality between VN-Index, VN30 and GDP based on VAR model. The hypothesis $\mathrm{H}_{0}$ is that no causal relationship is found.

Table 4: Results of Test for Causal Relationship between GDP and VN-Index

Dependent variable: D(GDP,2)

\begin{tabular}{lccc}
\hline Exogenous variable & Chi-sq & df & Prob. \\
\hline D(VNINDEX,2) & 2.892518 & 3 & 0.4085 \\
Dependent variable: D(VNINDEX,2) & & \\
Exogenous variable & Chi-sq & df & Prob. \\
D(GDP, 2$)$ & 2.232671 & 3 & 0.5255 \\
\hline
\end{tabular}

Source: Author's calculations

Table 5: Results of Test for Causal Relationship between GDP and VN30

Dependent variable: D(GDP,2)

\begin{tabular}{lccc}
\hline Exogenous variable & Chi-sq & df & Prob. \\
\hline $\mathrm{D}(\mathrm{VN} 30,2)$ & 1.547738 & 3 & 0.6713
\end{tabular}

Dependent variable: D(VN30,2)

$\begin{array}{lccc}\text { Exogenous variable } & \text { Chi-sq } & \text { df } & \text { Prob. } \\ \text { D(GDP, } 2) & 4.289763 & 3 & 0.2318\end{array}$

Source: Author's calculations

Tables 4 and 5 indicate that the $\mathrm{H}_{0}$ is accepted and there is no evidence of a causal relationship between GDP and VN-Index, as well as between GDP and VN30. 


\section{d. Impulse Response:}

Response to Cholesky One S.D. Innovations \pm 2 S.E.

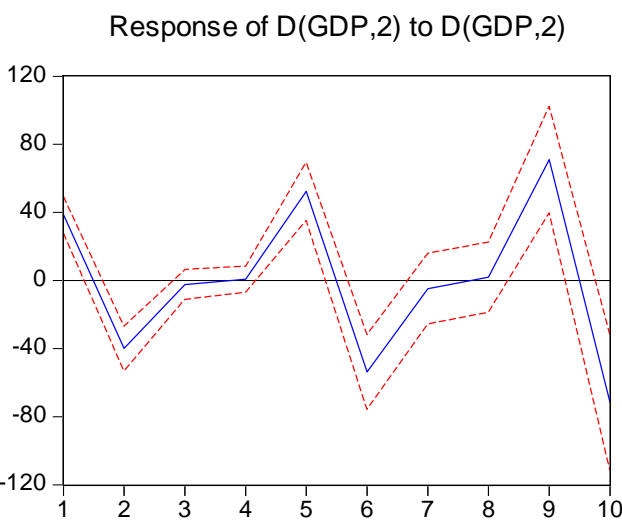

Response of $\mathrm{D}(\mathrm{GDP}, 2)$ to $\mathrm{D}(\mathrm{VNINDEX}, 2)$

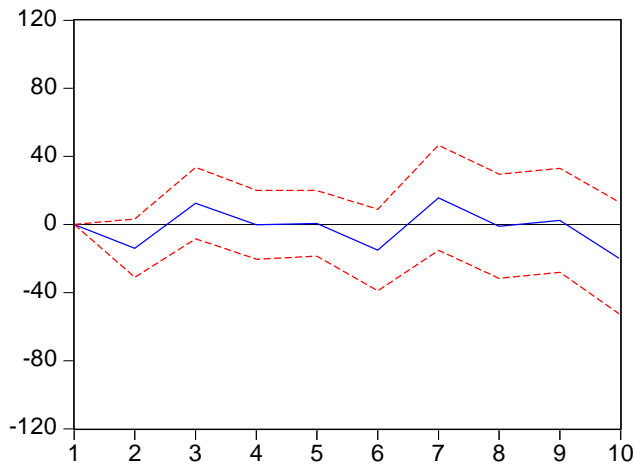

Response of $\mathrm{D}(\mathrm{VNINDEX}, 2)$ to $\mathrm{D}(\mathrm{GDP}, 2)$

Response of $\mathrm{D}(\mathrm{VNINDEX}, 2)$ to $\mathrm{D}(\mathrm{VNINDEX}, 2)$
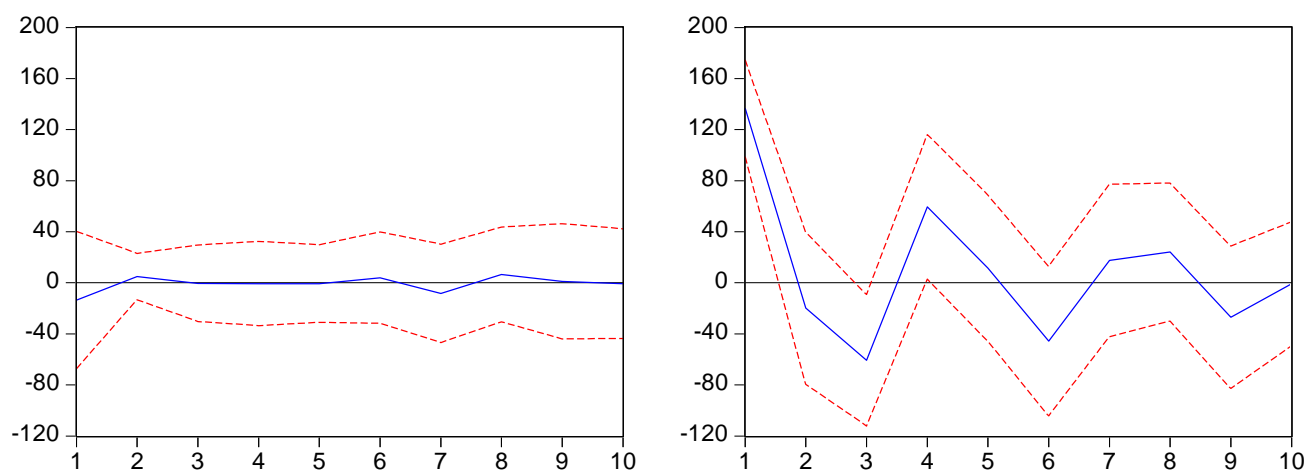

Source: Author's calculations

\section{Figure 1: Impulse Response of GDP to VN-Index}

Impulse response indicates impacts of GDP and VN-Index, in which exists an obscure trend and a gradual increase in fluctuations when cycles rise in impact of the GDP on itself (Autoregression). The opposite is true in the case of VN-Index when its impact gradually decreases when the cycle increases. Additionally, the results show the insignificant response of VN-Index to GDP and vice versa, clarifying a weak relationship, or even no relationship, between two variables. 
Response to Cholesky One S.D. Innovations \pm 2 S.E.
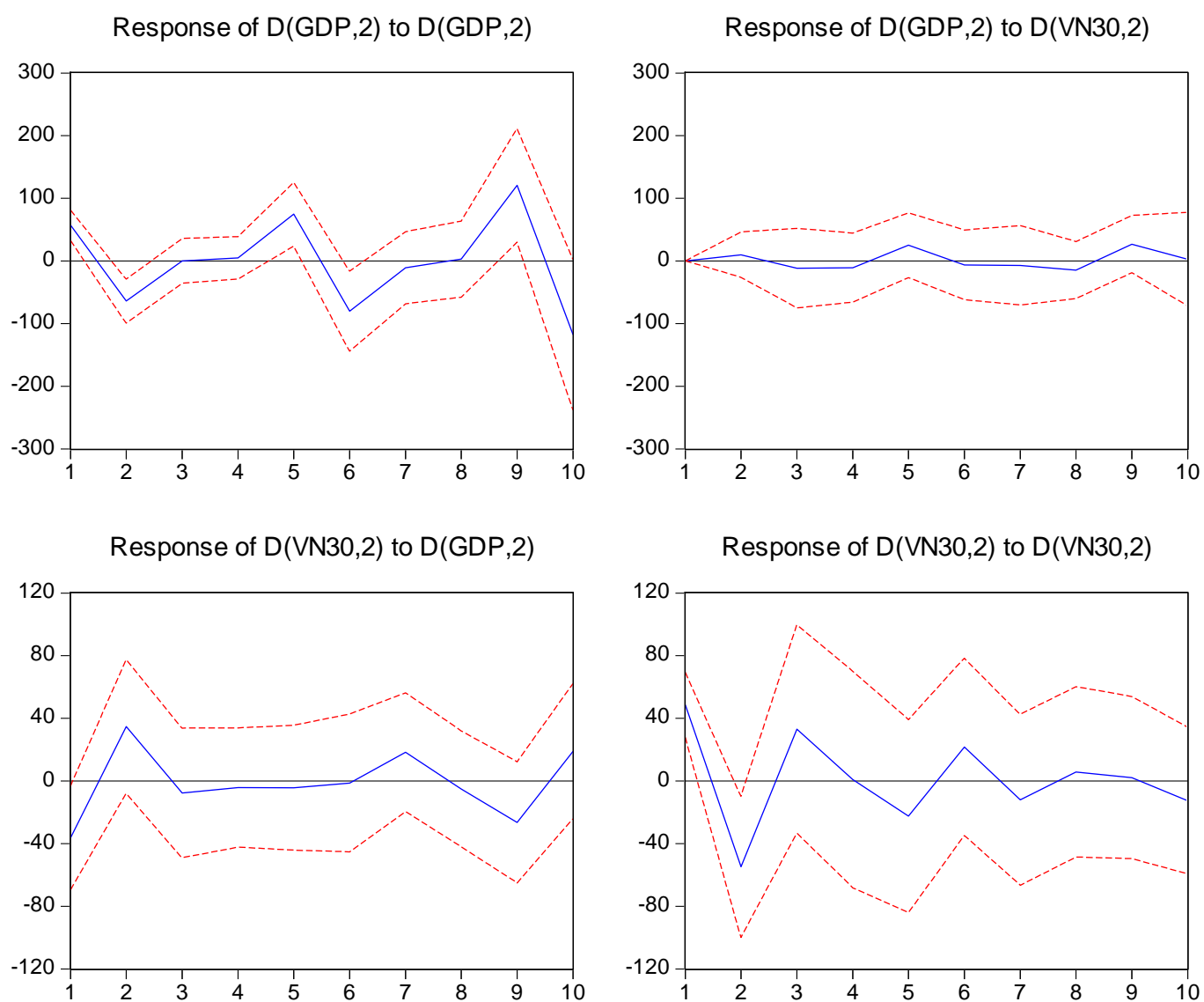

Source: Author's calculations

Figure 2: Impulse Response of GDP to VN30

The results show that there is no evidence of reciprocal impact between GDP and VN30, and there is evidence of impacts of GDP and VN30 on themselves.

\section{e.Variance decomposition:}

To correctly evaluate mutual explanation of two variables VN-Index, VN30 and GDP, the author analyzes variance decomposition to measure degrees of explanation between those two variables and detects their relationship in the cycle of 10 . The results are as follows: 
Table 6: Results of Analysis of Variance Decomposition of GDP and VN-Index

\begin{tabular}{cccc}
\hline Variance decomposition of D(GDP,2): & & & \\
\hline Cycle & S.E. & D(GDP,2) & D(VNINDEX,2) \\
\hline 6 & 96.38359 & 93.77474 & 6.225257 \\
7 & 97.75885 & 91.39437 & 8.605634 \\
8 & 97.78422 & 91.38655 & 8.613448 \\
9 & 120.8790 & 94.32460 & 5.675404 \\
\hline 10 & 142.0753 & 93.82933 & 6.170668 \\
\hline Variance decomposition of D(VN-Index,2): & & \\
\hline Cycle & S.E. & D(GDP,2) & D(VN-Index,2) \\
\hline 6 & 169.5102 & 0.779084 & 99.22092 \\
7 & 170.6158 & 1.012452 & 98.98755 \\
9 & 172.4229 & 1.130527 & 98.86947 \\
\hline 10 & 174.5282 & 1.107108 & 98.89289 \\
\hline
\end{tabular}

Source: Author's calculations

Analysis of variance decomposition shows that VN-Index may explain only $6.2 \%$ of changes in GDP, and GDP can explain 93.8\% of changes in itself while VN-Index can explain only $1.1 \%$ of forecast of changes in the GDP, and the rest are changes in VNIndex in itself.

Furthermore, analysis of decomposition of the variance of VN30 and GDP indicates that VN30 explains only $4 \%$ of changes in GDP while GDP may explain 34\% of change in $\mathrm{VN} 30$.

As analyzed above, the research results indicate that there exists no evidence of the relationship between VN-Index, VN-30 and economic growth in Vietnam through the GDP in VAR model, causality test and analysis of impulse response. This analysis of variance decomposition also presents poor predictive power of VN-Index and VN30, only $1 \%$ and $4 \%$ respectively. 


\section{f. Testing Market Representativity of Stock Index:}

The author measures correlation coefficient between VN-Index, VN-Index2 and VN30 to evaluate their market representativity. In the case of VN-Index, the author removes four stock codes with highest capitalization value (VIS, MSN, VCB and VNM) which are considered as a cause of distortion of the stock market because they account for more than $40 \%$ of total capitalization value of the HOSE and affect greatly the VNIndex.

Table 7: Results of Coefficient of Correlation Matrix between VN30, VN-Index2 and VN-Index

\begin{tabular}{llll}
\hline & VN-Index & VN-Index2 & VN30 \\
\hline VN-Index & 1.000000 & 0.697549 & 0.771106 \\
VN-Index2 & 0.697549 & 1.000000 & 0.133163 \\
VN30 & 0.771106 & 0.133163 & 1.000000 \\
\hline
\end{tabular}

Source: HSX, HNX, and author's calculations

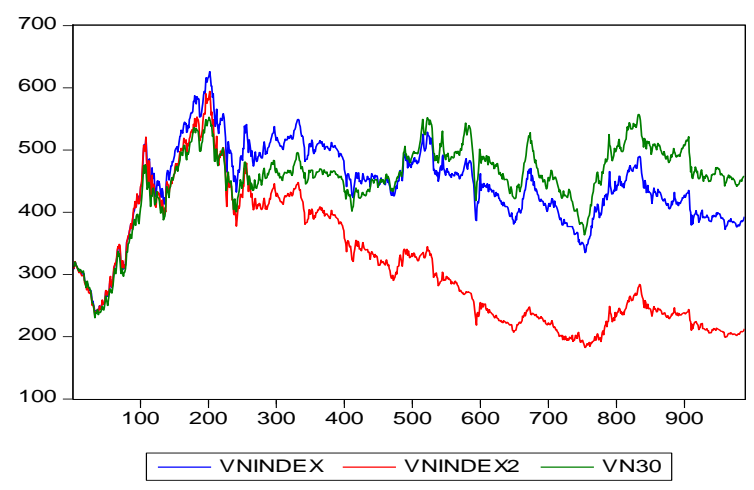

Figure 3: Relationship between VN30, VN-Index2 and VN-Index

The correlation between VN-Index and VN-Index 2 is close in the beginning, but they fall apart in the next period, when VN-Index remains at a high level and VN-Index2 tends to fall sharply after the $220^{\text {th }}$ observation. The reason is that the four aforementioned stock codes distorted the VN-Index: they continue to rise strongly while most other codes fell, making them cease to be effective representative indices of the market. 
Similarly, the results of analysis of correlation coefficient show a poor market representativity of VN-30, because coefficient of correlation between VN-30 and VNIndex 2 is low, at 0.133163 , when four leading stock codes are removed. Thus, VN30 does not meet expectations of their creators who want them to replace VN-Index because of its poor market representativity and reduce distortion of market indices.

\section{CONCLUSIONS}

Inadequacies of existing market indices are as follows:

- Poor market representativity;

- Low predictive power;

- Being affected by a group of stocks with high capitalization value, and

- Failure to serve as a basis for developing ETFs because it is computed from prices of all stocks in the market.

Thus, it is extremely essential for securities market in Vietnam to create a new index that is able to deal with inadequacies of existing indices in order to provide relevant entities with a general and clear view on development of stock market in Vietnam.

\section{SUGGESTIONS FOR A NEW STOCK MARKET INDEX IN VIETNAM}

Official stock market indices in Vietnam do not actually meet standards and requirements for a stock index in terms of market representativity, alternative commodity and economic predictive power. Moreover, due to the need to merge Hà Nội and Hồ Chí Minh stock exchanges in accordance with the government's plan to restructure the stock market, creating a common index for both stock exchanges is really an urgent requirement. Therefore, the author offers several recommendations on a new stock index:

\section{a. Building of VN-index in the Centralized Market:}

New stock index for a centralized stock market is based on the following criteria:

- Market representativity;

- Good predictive power; and

- Transferable commodities.

VN-Index is intended to provide investors, policy managers and relevant entities with a general and clear view of the stock exchanges on centralized stock markets in Vietnam.

Criteria for selecting stocks in set of indices and regular review 
Criteria for selecting stocks for VN-Index are as follows:

- Stocks that do not meet listing standards include:

+ Convertible stock and loan stock

+ Certificates of ETFs and mutual funds.

- Listing standards comprise:

+ All stocks that are traded and listed on HCMC and Hà Nội stock exchanges.

Chartered capital: The minimum chartered capital is required to be VND100 billion to ensure that all companies under consideration have good market representativity.

The average free float should be at least $50 \%$ of issued stocks (amount of stocks in circulation minus amount of restricted stocks, such as stocks owned by the state and others that are not fully transferable). This aims to restrict stocks that have high capitalization value but low liquidity and easily become target for price manipulation.

- Liquidity:

Method of capitalization ratio seems to be ineffective in Vietnam's stock market because of poor market representativity of stocks with high capitalization value but low liquidity. Thus, the selection of stocks to build a new index should be based their real transaction values.

- VN-Index includes 40 stock codes that are selected according to the following criteria:

+ Transaction value: Stocks with the highest average transaction values in three months in both Hà Nội and HCMC stock exchanges.

+ Shares of stocks in index basket: Calculation of these shares is based on ratio of capitalization value of selected stock codes to total capitalization value of index basket. Ratio of each stock is limited to the maximum level of $5 \%$ of total transaction values to restrict the effects of stocks with high capitalization value on the market.

Regulations on variables and changes of listed companies in the index basket:

- Price

Before merging stock exchange, real-time prices of stocks in both stock exchanges are used for calculating the VN-Index and prices will be updated every 15 minutes. 
After merging according to the project to restructure the stock market, real-time prices in the merged exchange are used for calculating the VN-Index that will be updated continuously according to real prices.

- Number of shares

The number of shares of component stocks is the number of the newest outstanding shares of those stocks. If issuance of shares of the listed company causes a large change in total ratio of indices (more than 5\%) compared to the base period, the change will be registered by the end of the quarter.

- Dividend

Dividend is included in the formula of VN-Index to evaluate the overall growth of stocks in VN-Index.

- Time for review of stocks in the index basket: Stocks in the index basket will be quarterly reviewed on the $25^{\text {th }}$ of the last month of the quarter, thereby removing stocks that cannot meet the standards while adding stocks that satisfy the standards to ensure that the basket always comprises 40 stock codes.

- Stocks added to the index basket: In every review, stocks that gain the highest average transaction values in the quarter and meet index criteria will be examined and added to the index basket by the Supervision Committee.

- Stocks removed from the index basket: Supervision Committee will remove stocks with low average transaction value in the quarter from the index basket in every review, and replace them with stocks that meet index criteria.

In cases of bankruptcy, dissolution, or M\&A, stocks of relevant companies will be removed from the index basket.

There are adjustments to stocks in the basket when:

- Companies are merged or acquired with others;

- Corporate capital is restructured; and

- Companies acquire, or merge with others.

Apart from the aforementioned cases, other changes will be added immediately to stocks in the basket.

Index Supervision Committee will evaluate, make appropriate adjustments in each review session and announce the results on the Friday of the final week of each quarter. 
Formula for calculating VN-Index:

Index $=\frac{\text { Current market capitalization value }}{\text { Divisor }}$

Where:

Current market capitalization value $=\mathrm{P}_{\mathrm{i}} \cdot \mathrm{Q}_{\mathrm{i}} \cdot \mathrm{c}_{\mathrm{i}}$

$\mathrm{P}_{\mathrm{i}}$ : Market price of stock $\mathrm{i}$

$\mathrm{Q}_{\mathrm{i}}$ : Quantity of outstanding stock i

$\mathrm{c}_{\mathrm{i}}$ : Stock weight limit, calculated according to the same formula for FTSE and VN30 but reduced to $5 \%$.

It is not necessary to include adjustment to capitalization value $f$ as in the case of VN30-Index and FTSE-Index because liquidity is the main criterion for selecting stocks for the index basket.

The formula for VN-Index in days with adjustments:

Indices indicate changes in stock prices; therefore, non-price factors causing index value to change are rejected in calculation.

In these cases, the divisor is adjusted to make the index have continuity and reflect correctly changes in prices in the market.

The general principle for adjustment: Total index value before changes/ Old divisor $=$ Total index value after changes/ New divisor

The weight of sectors in the index basket: In the VN-Index basket up to Dec. 12, 2012 , the weight of finance and banking sector is the highest (47\%) followed by manufacturing and consumer goods ones, with $24 \%$ and $11 \%$ respectively. 


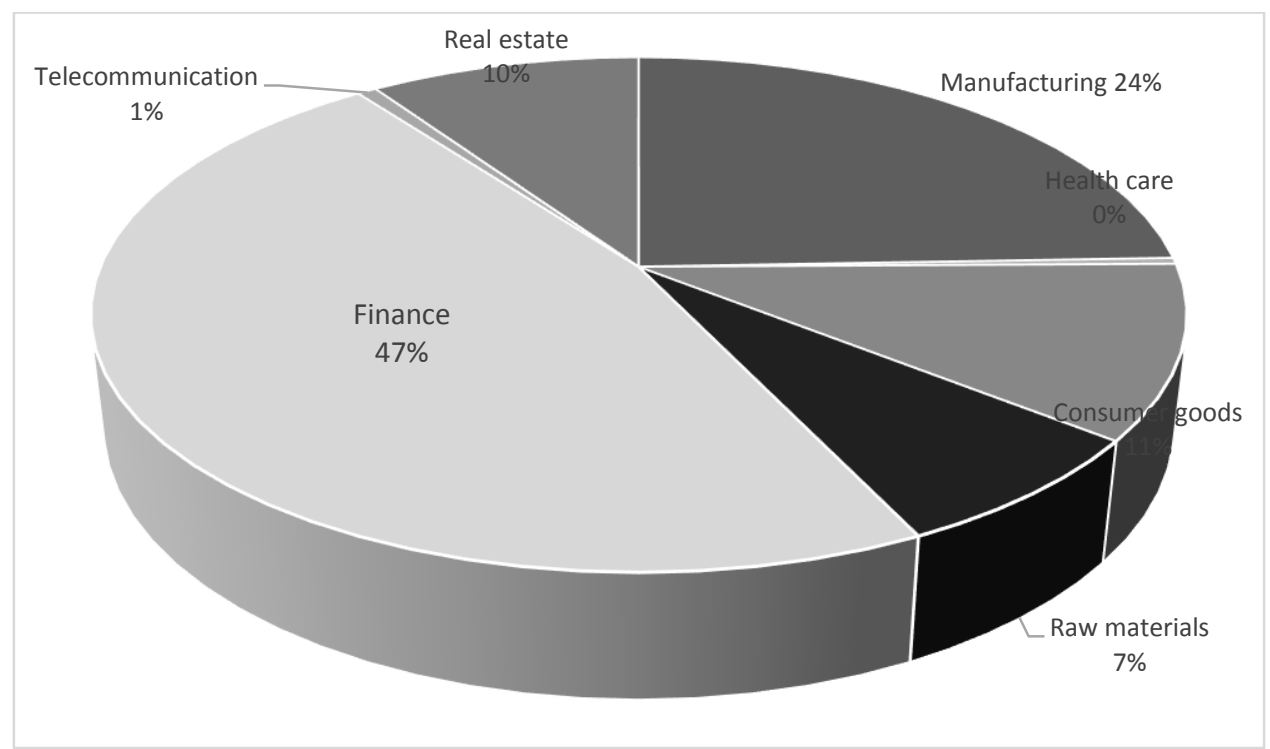

Source: HSX, HNX, and author's calculations ${ }^{[1]}$

\section{Figure 4: Weights of Sectors in VN-Index Basket}

Weights of currently listed stocks in the index basket: stocks listed in HOSE account for $78 \%$ of total capitalization weight in the index basket, and HNX-listed ones account for $22 \%$.

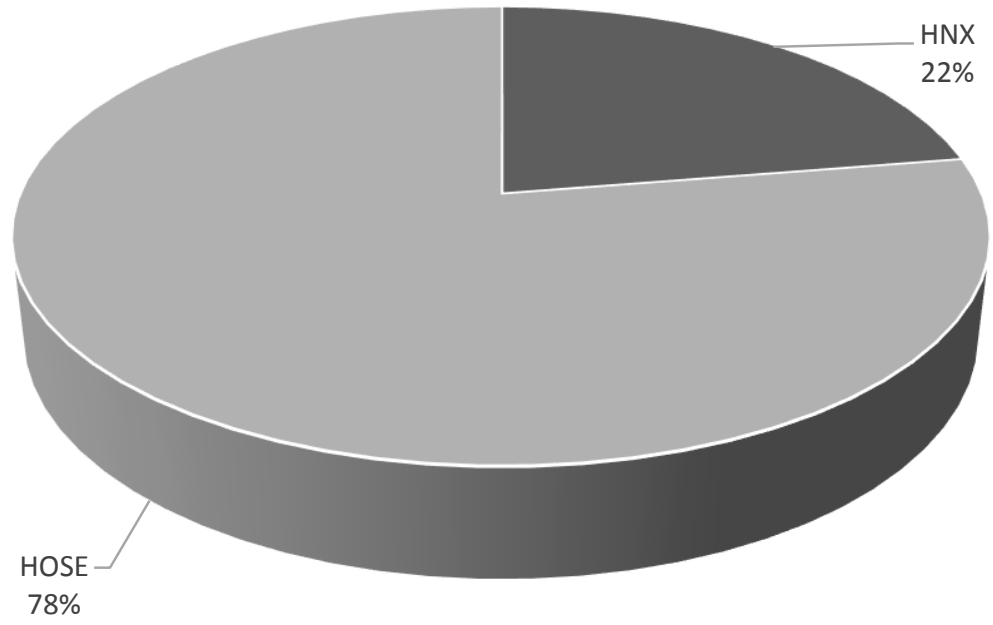

Source: HSX, HNX, and author's calculations

Figure 5: Weights of Stocks Listed in HOSE and HNX in VN-Index 
By overcoming shortcomings in present stock indices and adopting strengths of stock indices in well-developed stock exchanges, VN-Index is expected to replace present stocks by its effectiveness and appropriateness to Vietnam's stock market.

Structure of stocks in the index basket may change more quickly because the stock selection is based on average trading value in a quarter instead of the highest capitalization value, which forces ETFs to change their portfolio more frequently and helps improve the liquidity of the stock exchange.

According to the expectations theory, investors tend to invest in industries with bright prospects, increasing the liquidity of stocks in these sectors. Industries passing the peak of their development cycles will receive little attention from investors and their liquidity decreases. As a result, they will be removed from the basket in the next review. Using liquidity as criterion for selecting stocks can make the stock index reflect more closely fluctuations in the economy and offer good predictions to investors.

The index may decrease its dependency on stock codes with high capitalization value (even their liquidity is not high) due to the limit of $5 \%$ on capitalization weight, which helps limit distortion as in the case of VN30 where the capitalization weight of $10 \%$ is allowed. In the VN30, five stock codes that have the highest capitalization values account for $50 \%$ of total market capitalization of the whole index basket, and distortions of indices as in the case of VN-Index still occur.

\section{b. Supporting Solutions:}

To foster the role of the present stock indices in the stock market and in the whole economy, several supporting solutions besides adjustments to calculating methods are much needed.

- Establishing an Index Supervision Committee:

Established by the State Securities Commission, Index Supervision Committee is responsible for making decisions on indices such as on the stock basket used for the index or changes in stock basket during review sessions. Moreover, it also undertakes control and supervision of fluctuations in the stock index.

- Improving the market regulation function:

Governmental agencies should manage well the stock market, frequently conduct investigations and supervision on transactions in stock exchanges to make information more transparent and avoid information asymmetry. 
Preventing, investigating and handling insider trading and market manipulation should be carried properly to limit price manipulation and index distortion by organizations or individuals.

Shortening the transaction time is also a measure to increase the liquidity of stock market and reduce price manipulation.

Moreover, the stock market needs restructuring according to the plan suggested by the government, which gives top priority to a merger of Hà Nội and HCMC stock exchanges, to make transactions on a centralized market smooth and consistent.

- Disseminating knowledge of securities market among investors:

Studying and supplying knowledge of securities market are conducted by both securities authorities and various universities in Vietnam. However, those who get access to such knowledge comprise mainly university students and persons working in stock exchanges. This field is still unfamiliar to the public, making participants in the stock market a very small group compared to the population. Additionally, those participants usually lack necessary knowledge and tend to follow herd instinct, which prevents stock indices from reflecting real incidents in the market. Therefore, research and dissemination of knowledge about securities market is an urgent matter that can be solved by taking various measures:

+ Courses in securities market given regularly by the Securities Research and Training Center under the State Securities Commission are very useful. The Center could give more short-term courses in community centers of youth cultural houses to provide local residents with opportunities to get useful knowledge.

+ It is necessary to set up an official program to give training in stocks. Universities should develop courses in securities and finance market including highly-specialized subjects.

- Establishing Credit Rating Agency in Vietnam:

Credit rating agencies play an important role in stock markets, providing investors with in-depth information and analyses to help them gain a clear view on the growth of stock market and indices. Thus, building a system of credit rating agencies in Vietnam will make the operation of the stock market and price indices more effective.

The following problems should be addressed to help credit rating agencies establish, survive and develop in the infant stock market in Vietnam: 
+ A legal framework for operation of credit rating agencies should be introduced. Rules and regulations on such agencies should be added to the Securities Law. For the time being, the government could issue a decree introducing some basic guidelines on operations of such agencies since they are totally new to Vietnam's financial market. Additionally, awareness of importance of credit rate among share issuers and investors should be enhanced.

+ The legal infrastructure should ensure independence for these agencies because it is a decisive factor in their success and trustworthiness. This independence allows them to offer objective reports and judgments about issuing organizations.

+ Vietnam should cooperate with international credit rating agencies to acquire their expertise and experience to build successful credit rating agency and avoid mistake in developing this service.

+ At present, it is very useful to turn the Credit Information Center (CIC) into a credit rating agency. CIC produces annual assessments of creditworthiness of listed companies. Although quality of information it provides is not very high, there are many advantages when moving into the new service.

It is worth noting that establishment of credit rating agencies in Vietnam should be carefully carried out to ensure the necessary professionalism. A state-owned credit rating agency can be built in the first stage and then could be privatized

\section{Note:}

[1] Data are collated from Hà Nội and HCMC stock exchanges, and General Statistics Office.

\section{References}

Adamopoulos, A. (2010), "Stock Market and Economic Growth: An Empirical Analysis for Germany", Business and Economics Journal, Vol. 2010: BEJ-1.

Ake, B. \& J. Dehuan (2010), “The Role of Stock Market Development in Economic Growth: Evidence from Some Euronext Countries”, International Journal of Financial Research, Vol. 1, No. 1, pp. 14-20.

Ake, B. \& R.W. Ognaligui (2010), "Financial Stock Market and Economic Growth in Developing Countries: The Case of Douala Stock Exchange in Cameroon", International Journal of Business and Management, Vol. 5, No. 5, pp. 82-88.

Atje, R. \& B. Jovanovic (1993), "Stock Markets and Development", European Economic Review, Elsevier, Vol. 37(2/3), pp. 632-640. 
Bencivenga, V. R. \& B.D. Smith (1991), "Financial Intermediation and Endogenous Growth", Review of Economic Studies, Vol.58, No.2, pp. 195-209.

CFA Program Curriculum (2012), Security Market Indices, Volume 5, Level 1.

Dailami, M. \& M. Atkin (1990), Stock Markets in Developing Countries: Key Issues and a Research Agenda, Country Economics Department the World Bank, Economics Department International Finance Corporation, Working papers 515, pp. 1-49.

Deb, S. G. \& J. Mukherjee (2008), "Does Stock Market Development Cause Economic Growth? A Time Series Analysis for Indian Economy”, International Research Journal of Finance and Economics, Issue 21, pp. 142-149.

Demirgüç-Kunt, A. \& R. Levine(1996), "Stock Markets, Corporate Finance, and Economic Growth: An Overview", The World Bank Economic Review, Vol. 10, No. 2, pp. 223-239.

Enisan, A. A. \& A.O. Olufisayo (2009), "Stock Market Development and Economic Growth: Evidence from Seven Sub-Sahara African Countries", Journal of Economics \& Business, Vol. 61(2), 162-171.

Goldsmith, R.W. (1969), Financial Structure and Development, New Haven, Coon, Yale University Press.

Greenwood, J. \& B. Jovanovic (1990), "Financial Development, Growth, and the Distribution of Income”, Journal of Political Economy, University of Chicago Press, Vol. 98(5), pp. 1076- 1107.

Harris, R.D.F. (1997), “Stock Markets and Development: A Re-Assessment”, European Economic Review, Vol. 41, No. 1, pp. 139-146.

King, R. \& R. Levine (1993), "Finance, Entrepreneurship and Growth", Journal of Monetary Economics, Vol.32, pp.513-542.

King, R. \& R. Levine (1993), "Finance and Growth, Schumpeter Might Be Right”, The Quarterly Journal of Economics, Vol. 108 (3), pp.717-737.

Levine, R. (1997), "Stock Markets Economic Development and Capital Control Liberalization”, Perspective, Vol. 3, No. 5, pp.1-8, Investment Company Institute.

McKinnon, R. (1973), Money and Capital in Economic Development, Brookings Institution, Washington, D.C.

McMillan, M.G., J.E. Pinto, W. Pirie \& G. Van de Venter (2011), Investments: Principles of Portfolio and Equity Analysis, John Wiley \& Sons

Pagano, K. (1993), "Financial Markets and Growth: An Overview”, European Economic Review, 37(2/3), pp.613-622.

Sandte, H. (2012), "Stock Market vs. GDP Growth: A Complicated Mixture”, Viewpoint, BNY Mellon Asset Management.

Shaw, E. S. (1973), Financial Deepening in Economic Development, New York: Oxford University Press. 